\title{
SCANNING ELECTRON MICROSCOPY \\ OF VEGETATIVE AND REPRODUCTIVE STRUCTURES FROM Beauveria bassiana (Bals.) Vuill. STRAINS STORED IN MINERAL OIL
}

\section{(Microscopia eletrónica de barrido de estructuras vegetativas y reproductivas de cepas de Beauveria bassiana (Balls.) Vuill. conservadas en aceite mineral)}

\author{
Laura Mesquita Paiva ${ }^{1}$ \\ Isaíras Pereira Padovan ${ }^{2}$ \\ Elza Áurea de Luna-Alves Lima ${ }^{1}$ \\ ${ }^{1}$ Universidade Federal de Pernambuco, Departamento de Micologia, \\ Av. Nelson Chaves S/N-Cid.Universitária CEP:50670-420-Recife/PE/Brasil. \\ ${ }^{2}$ Departamento de Histologia e Embriologia-CCB-Universidade Federal de Pernambuco
}

Palabras-clave: Beauveria bassiana, microscopia electrónica de barrido, conidiogénesis.

Key words: Beauveria bassiana, scanning electron microscopy, conidiogenesis

\section{SUMMARY}

The morfogenesis of Beauveria bassiana strains stored for seven years in mineral oil and others more recently isolated from the field and maintained in agar media, were observed with a scanning electron microscopy. The simpodially proliferating conidiogenous cell model with holoblastic conidial development was observed regularly. No significant morphological alteration was detected in the development of conidiogenesis in the strains conserved in mineral oil in relation to the ones recently isolated, proving the efficiency of the method of preservation in mineral oil for these species.

\section{INTRODUCTION}

Beauveria bassiana (Balsamo) Vuillemin, is an entomopathogen fungus widely spread in soils, occurring in a broad variety of about 200 host insect species $(1,14)$. It appears to be potentially effective in the biological control of insect pests $(2,7,18)$, and in the United States this fungus is being used increasingly in the control of a number of insects affecting agriculture, such as the citrus acarid (11, 12). In Brazil, Specht et al. (21) researched an alternative to control population density in the leaf-

\section{RESUMEN}

Se estudió por microscopia electrónica de barrido, la morfogénesis de cepas de Beauveria bassiana mantenidas en aceite mineral durante 7 años, comparandolas con otras más recientes conservadas en medios agarizados. Se observó regularmente el clásico modelo simpodial con proliferación de la célula conidiógena y el desarrollo conidial holoblástico. La conidiogénesis de ambos grupos de cepas presentó pocas diferenciasmorfológicas, comprobandose que el método de conservación en aceite mineral, no afectamayormente a esta especie en este lapso de tiempo.

cutting ants Atta and Acromyrex, which are responsible for large crop losses in neotropical regions. Research tests showed that B. bassiana is extremely attractive as bait, being carried off during a 9 to 12 hours period, after being exposed in an open field.

Few electron microscopy studies have been conducted on B. bassiana. Reisinger \& Olah(19), began to work in this area, with their research into the ultrastructural and cytochemical aspects of conidiogenesis. Later, Pekrul \& Grula (16) used scanning electron microscopic techniques to show the hyphal penetration of 
B. bassiana in the tegument of the larva of Heliothis zea. They demonstrated that the fungus's germinative tube penetrated through the insect's spiracle and proliferated extensively reaching the haemolymph. Boucias et al. (5), observed in a scanning electron microscope, that B. bassiana conidia adhered to Anticarsia gemmatalis larvae, and they analysed the organization of the layers component of the conidium wall.

With this context in mind, along with the need to understand the biological phenomena related to the preservation of such important fungi, the present work has aimed to examine under a scanning electron microscopy, comparative aspects of the morphology of strains stored for a long period in mineral oil and others more recent isolated and conserved in agar media, in the first 48 hours of the development of conidiogenesis.

\section{MATERIALS AND METHODS}

1. Fungal strains: Three strains of $\boldsymbol{B}$. bassiana $\mathrm{PR}_{4}, \mathrm{PR}_{5}$ and $\mathrm{SP}_{6}$ were conserved in mineral oil for seven years in the UFPE Department of Micology (URM), which made them available for the present studies, while three other strains $\mathrm{PB}_{1}, \mathrm{PE}_{2}$ and $\mathrm{PE}_{3}$ were isolated from insects collected in the field and conserved in PDA (Table 1).

2. Culture media: The strains which were stored in mineral oil (Nujol) for seven years, have been reactivated in test tubes containing $10 \mathrm{ml}$ of glycoside broth $(20 \mathrm{~g}$ sucrose), $3 \mathrm{~g}$ meat extract, $10 \mathrm{~g}$ peptone and $1000 \mathrm{ml}$ distilled water. Following sporulation they were transfered to complete medium (CM) described by Pontecorvo et al. (17), the same as the control strains not maintained in mineral oil.

Table 1. Strains of B. bassiana, their respective hosts, and places and years of origin.

\begin{tabular}{|llll|}
\hline Strain & Code of origin & Host & Place of isolation/Year \\
\hline $\mathbf{P B}_{1}$ & URM 3331 & Schistocerca americana & Campina Grande 1992 \\
$\mathbf{P E}_{2}$ & URM 3447 & Castnia licus & Campina 1994 \\
$\mathbf{P E}_{3}$ & IPA 149 & Anthonomus grandis & Recife 1990 \\
\hline $\mathbf{P E}_{4}$ & URM 2930 & Euchistus heros & Londrina 1987 \\
$\mathbf{P R}_{5}$ & URM 2913 & Nezara viridula & Londrina 1987 \\
$\mathbf{S P}_{6}$ & URM 2935 & Hypothenemus hampei & Piracicaba 1987 \\
\hline
\end{tabular}

Strains were cultured for $2-3$ days at $20^{\circ}-22^{\circ} \mathrm{C}$ while preparations for the electron microscopy were carried out at the end of the second and third day.

3. Scanning electron microscopy: $\mathrm{A} 1 \mathrm{~cm}^{2}$ piece of dialysis membrane : with the fungus was fixed in a solution containing glutaraldehyde $(2.5 \%)$ and stabilized in a solution of sodium cacodilate $(0.1 \mathrm{M})$ for two hours. Then it was washed three times in stabilizing solution of sodium cacodilate $(0.1 \mathrm{M})$, for five minutes each wash. Following this, it was post-fixed for one hour in an osmium tetroxide solution (1\%) and then submitted to dehydration in ethylene series of $50 \%, 70 \%, 90 \%$ and $100 \%$, remaining in each stage for 10 minutes. It was desiccated in a critical point dryer, and then metalized in gold in a Fine Coat Ion Sputter (Jeol brand, model JFC-1 100). The observations were made in a Jeol scanning electron microscope, model JSM-T 200.

4. Electron microscopy: The electronmicrographs were taken on Neopan SS film, 120 ASA, and produced on F-3 photographic paper, with Dektol developer and
Kodak fixer.

\section{RESULTS AND DISCUSSION}

The morphological aspects of the study of the strains not conserved in mineral oil can be observed in Figure 1, with the representative strains $\left(\mathrm{PE}_{2}\right)$.

Strain PB $\mathbf{P B}_{1}$. Polar germination of the conidia was observed, along with intense hyphal anastomosis. The reproductive structures, and conidiogenous cell (CC) with terminal conidia formations are early formed. Intercalary primordium of $\mathrm{CC}$ at an initial stage of differentiation, was observed.

Strain $\mathrm{PE}_{2}$. The results obtained made possible to identify anastomosis and hyphal septa in the mycelium (Figure 1. A-B). Elongation of the tip of CC after the first conidium (1B), and 2 conidiogenous loci without elongation is observed (1B) Figure 1.C-F shows the developmental stages of conidiogenesis. The intercalary conidiophore in initial stage of development, the apex of $\mathrm{CC}$, and globose conidia are formed in apparently straight denticulate rachis (Figure 1.C). Figure 1.D-F, shows 

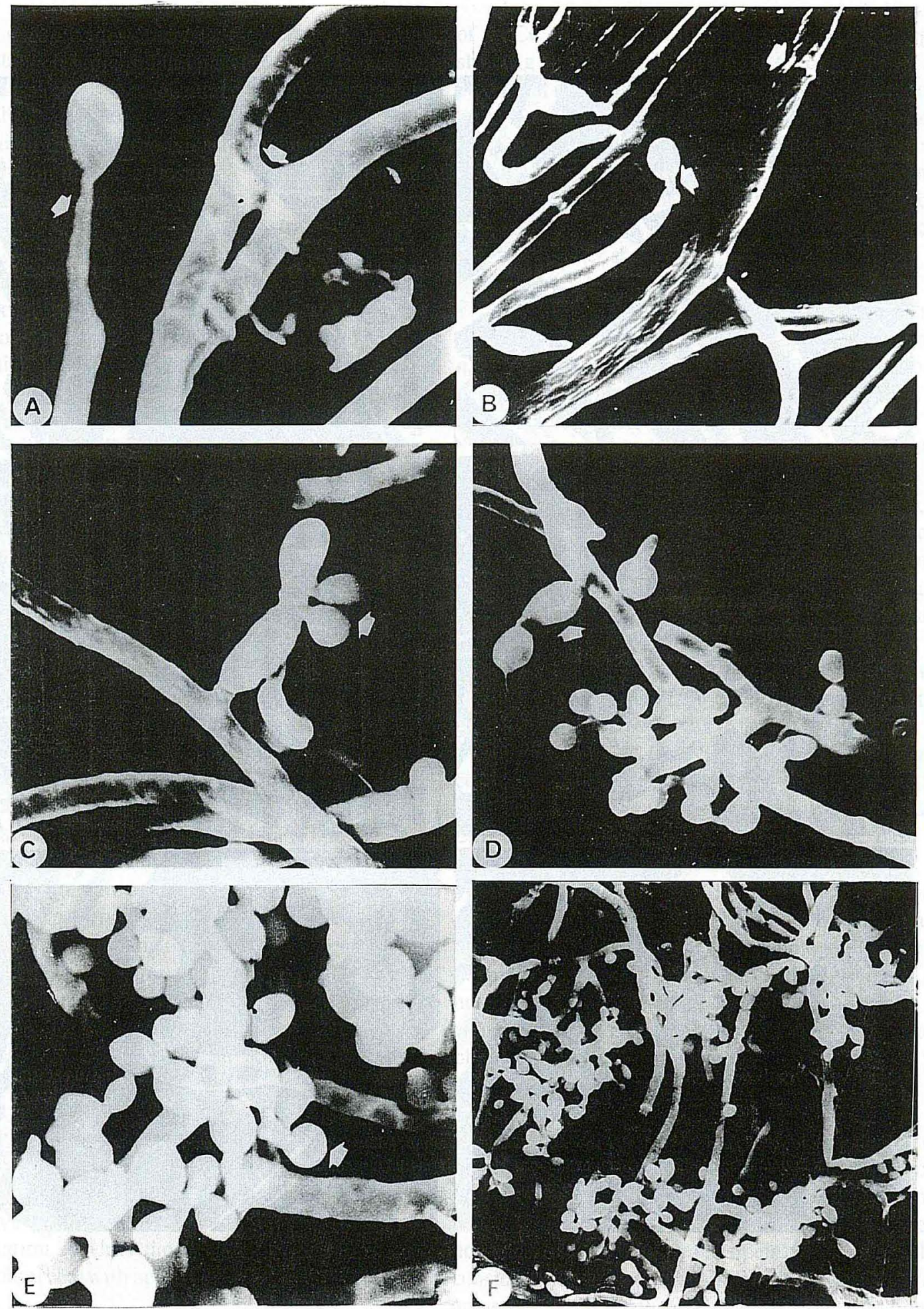

Figure 1. - Electron micrograp'ly of B. bassiana not conseived in mineral oil. Strain $\mathrm{PE}_{2}$ in Complete Medium with 48 hours of growth. a. Terminal conidiogenous cell (arrow) and anastomosis (arrow), 10.000x; b. Apical conidiogenous cell displaying conidium in initial phase in zigzag (arrow) and conspicuous hyphal septum (arrow), 5.000x; c. Intercalary conidiophore in initial stage of development. Conidia (arrow) are present, 6800x; d.-- Intercalary conidiogenous cell(arrow) at advanced stage of development $5.000 \mathrm{x}$; e. Abundant conidiogenous cell displaying globose conidia (arrow) 6.800x; f. Groups of conidiogenous cell, $2.300 \mathrm{x}$. 

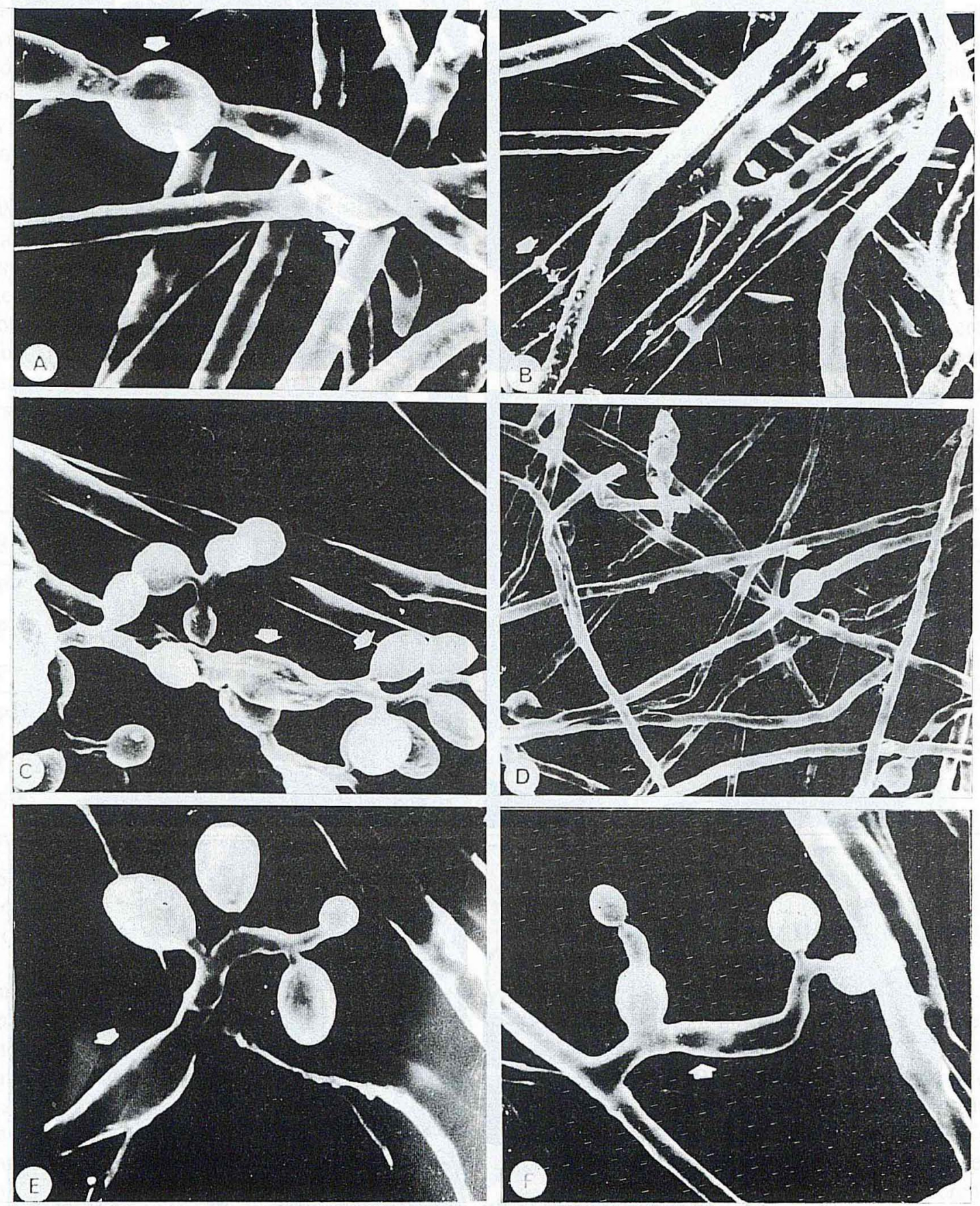

Figure 2. Electron micrography of B. bassiana conserved in mineral oil . Strain $\mathrm{PR}_{5}$ in Complete Medium with 48 hours of growth. a. Germinating conidia, mycelium at advanced stage of development, with initiation site still present (arrows) $10.000 \mathrm{x} ; \mathbf{b}$. Mycelium displaying hyphae, septum and anastomosis (arrows) $5.000 \mathrm{x}$; c. Successive apices of sympodially proliferating conidiogenous cell (arrows), $5.000 \mathrm{x}$; d. Germinating conidia with mycelium at an advanced stage of development displaying initiation site (arrows) and absence of anastomosis 3.000x; e. Conidiogenous cell displaying conidia at distinct stages of development (arrow) $7.000 \mathrm{x}$; f. Anomalous conidiophore and conidiogenous cell displaying globose conidia (arrow), 5.000x. 
intercalary conidiophores in small clusters at early and advanced stages of development.

Strain $\mathbf{P E}_{3}$. Innumerable anastomosis were observed, along with the formation of $\mathrm{CC}$ at an early stage of differentiation, revealing tipical elongation of $\mathrm{CC}$ in zigzag, similar to strain $\mathrm{PE}_{2}$.

The morphological aspects of the strains preserved in mineral oil can be seen in Figure 2, with the representative strain $\left(\mathrm{PR}_{5}\right)$.

Strain $\mathbf{P R}_{4}$. Hyphal anastomosis in mycelial development was observed. Globose conidia and bottleshaped conidiophores with simpodial elongations (zigzag) were observed frequently during the observation period. Similar morphological descriptions was made by Benham \& Miranda (4) and De Hoog (6) .

Strain $\mathbf{P R}_{5}$. The vegetative growth is documented in Figure 2.A, B, D; in which initiation sites of development were observed, represented by the polar germination of globose conidia (Figure 2.A, D), anastomosis, and hyphal septa (Figure 2.B). The formation of reproductive structures, of geniculate denticulate rachis of $\mathrm{CC}$, were identified at various stages of differentiation, as it is shown in Figure. 2.C.

Analysing the morphology of the reproductive structures of strains $\mathrm{PR}_{4}$ and $\mathrm{PR}_{5}$, it was possible to detect the conidiogenesis that is characteristic of the specie in all their phases of development, from the formation of the $\mathrm{CC}$, in which two conidia were observed, to the formation of mature rachis exhibiting seven conidia (Figure 2.C).

Strain SP $_{6}$. Thick and thin hyphae could be seen in formation and remainder of the conidium from which the mycelium was originated. The anastomosis was not detected in this strain during the observation period. This fact arises from the rapid growth of the strain. In contrast, in the strains $\mathrm{PR}_{4}$ and $\mathrm{PR}_{5}$, no conidiophores were identified in early stages, although conidia in isolated cluster were observed frequently in $\mathrm{CC}$ at an advanced stage of differentiation.

Examining the behaviour of the strains $\mathrm{PB}_{1}, \mathrm{PE}_{2}$ and $\mathrm{PE}_{3}$, which had not been conserved in mineral oil, it was verified that all the morphological stages of conidiogenesis, which began with the formation of the primordium of $\mathrm{CC}$, evolved into a more advanced stage of differentiation, in which the beginning of the formation of $\mathrm{CC}$ was observed with apical or several conidia on the upper part.

The sequence of conidiogenesis was complemented with an analysis of the strains stored in mineral oil $\left(\mathrm{PR}_{4}\right.$, $\mathrm{PR}_{5}$ and $\mathrm{SP}_{6}$ ). Conidiophore with 3 conidia on the upper conidiogenous cells with a more advanced stage (Figure 2 .E), in which the formation of conidiophores can be observed displaying 4 conidia at their apex at distinct stages of differentiation. They culminate in the formation of a $\mathrm{CC}$ at a more advanced stage of development, showing the wrinkled wall with 6 conidia in a zigzag position at its apex (Figure 2.C). They finish with secession of the conidia, in which it is no longer possible to identify the CC. These data match with the results analysed through a light microscope $(3,15)$, accompanying the same stages and nuclear condition. In every case the strain $\mathrm{SP}_{6}$ stood out, with its conidiogenesis being faster than that of the other strains.

Many fungi survive in unfavorable periods by their spore of resistence such as clamidospore. In B. bassia$\boldsymbol{n} \boldsymbol{a}$, no clamidospore are formed and survive for long periods in dead insect, in conidial or mycelial forms which have an average life of 273 days at $10^{\circ} \mathrm{C}(10)$.

DeHoog (6), observed considerable morphological variability in the genera, infuenced by the age of the isolates, the moisture and culture media. However, in our isolations not maintained in mineral oil (as in the control group), major differences were not observed in their conidiogenesis. Maybe in the last, mostly forming more little clusters of $\mathrm{CC}$ (generally 2-7 group of CC, or single). that the conserved in mineral oil.

We have observed several types of $\mathrm{CC}$ : without elongation, geniculate-denticulate rachis (majority) and geniculate-cicatrized rachis (6).

Kendrick \& Cole (9) show the conidium and conidiophore ontogeny of Beauveria globulifera (Speg.) Picard (=B. bassiana), is comparable to Tritirachium Limber and the septal development at the base of the conidium is by a schizolysis process (19).

Tolypocladium W. Gams, cannot be satisfactorily separated from Beauveria, because they resemble in macroscopic and microscopic morphologies, specially for the presence of flask-shaped CC with thin necks. Althouth Beauveria spp., produce sympodial conidia on an elongating rachis, while the former produce conidia on phialides. These differences are less evident in young cultures $(20,21,22)$.

Minter et al. (13), research the history of the term phialide, they shows that conidiogenous cells of this fungus have the right shape for a phialide in Vuillenmin's sense, but develop by sympodial proliferation and therefore do not produce conidia in a basipetal succession. There is considerable evidence that Vuillemin's was aware of this anomaly and, nevertheless, regarded the conidiogenous cells of $\boldsymbol{B}$. bassiana as phialides.

It was thus demonstrated that the technique of preserving this fungus in mineral oil was efficient, and did not harm the fungus at any phase of the development of conidiogenesis in seven years. 


\section{ACKNOWLEDGMENTS}

The authors would like to thank the Keizo Asami Imunopathology Laboratory of Universidade Federal de
Pernambuco, Recife - PE, for kindly allowing them to use its electron microscope. They are also grateful to the $\mathrm{CNPq}$ for financial assistance.

\section{REFERENCES}

1. Alves, S. B. (1986). Fungos Entomopatogênicos. In: Alves, S. B., coord Controle Microbiano de Insetos. Manole, São Paulo, pp.73-126

2. --.-.-.(1992). Perspectivas para utilização de fungos Entomopatogênicos no controle de pragas no Brasil. Pes. Agropec. Brasil 27:77-86 Edição Especial.

3. Azevedo, J. L.; Costa, S. O. P. (1973). Exercicios Práticos de Genética Nacional e EDUSP, São Paulo.

4. Benham, R. W.; Miranda, J. L. (1953). The genus Beauveria, morfological and taxonomical studies of several species and of two strains isolated from wharf-piling Borers. Mycologia 45:727-746

5. Boucias, D. G.; Pendland, J. C.; Latge, J. P. (1988). Monospecific factors involved in attachment of entomopathogenic Deuteromycetes to host insect cuticle. Appl. Environ. Microbiol 54:1795-1805

6. De Hoog, C. S. (1972). The genera Beauveria, Isaria, Tritirachium, and Acrodontium gen. nov. Stud. Mycol 1:1-41

7. Ferron, P. (1978). Biological control of insect pests by entomogenous fungi. Amn. Rev. Entomol. 23:409-442

8. --.-.-. (1981). Pest control by the fungi Beauveria and Metarhizium. In: Burges, H. P. (ed.) Microbial control of pests and plant diseases 1970-1980. Academic Press, London. pp. 465-482

9. Kendrick, W. B.; Cole, G. T. (1968). Conidium ontogeny in hyphomycetes. The sympodulae of Beauveria and Cuvurlaria. Canadian Journal of Botany 46:1297-1301

10. Lingg ,A.J. J.\& Donaldson, M.D. (1981). Biotic and abiotic factors affecting stability of Beauveria bassiana conidia in soil. J. Invertebr. Pathol. 38:191-200

11. McCoy, C. W. (1990). Entomogenous fungi as microbial pesticides In: Baker, R. R.; Dunn, P. E. (ed.) New directions in biological control: alternatives for suppressing agricultural pests and diseases.: Alan R. Liss, New York, pp.139-159.

12. .------ ;igano-Milan, M. S. (1992). Use of entomopathogenic fungi in Biological control: A world view. Pes. Agropec. Brasil 27: $87-93$
13. Minter, D. W.; Sutton, B. C.; Brady, B. L. (1983). What are phialides anyway? Trans. Br. mycol. Soc. 81:109-120

14. Moscardi, F. (1983). Microbial control of insect pests in grain legume crops. In: International Worshop in integrated pest control for grain legumes, Goiânia, EMBRAPA, pp. 189-222.

15. Paiva, L. M. (1994). Análise comparativa do crescimento e das caracteristicas citológicas de linhagens de Beauveria bassiana (Bals.) Vuill. emmicroscopia de varredura e de luz. Recife(Tese de Mestrado, Centro de Cièncias Biológicas, UFPE)

16. Pekrul, S.; Grula, E. A. (1979). Mode of infection of the corn earworm (Heliothis zea) by Beauveria bassiana as revealed by scanning electrone microscopy. J. Inverteb. Pathol. 34:238-247

17. Pontecorvo, G.; Roper, J. A ; Henmons, L. M.; Macdonald, K. D. (1953). The genetics of Aspergillus nidulans. Adv. Genet 5:141238.

18. Quintela, E. D.; Wraight, S. P.; Quinderé, M. A. W. (1994) Aplicação de conidios de Beauveria bassiana (Bals.) Vuill. e Metarhizium anisopliae (Metsch.) Sor. para controle de larvas de Chalcodermus bimaculatus Boh. (Coleoptera: Curculionidae) no solo. An.Soc.Entomol.Brasil 23:367-383

19. Reisinger, O. \& Oláh, G.M. (1974). Étude ultrastruturale et cytochimique de la conidogénese chez Beauveria bassiana (Bals.) Vuill. Can. J. Microbiol. 20:1387-1397

20. Samson, R.A .\& Soares G.G.Jr . (1984). Entomopathogenic species of the Hyphomycete genus Tolypocladim. Journal of invertebrate pathology 43:133-139

21. Specht, A.; Diehl-Fleig, E.; Silva, M. E. (1994). Atratividade de iscas de Beauveria bassiana (Bals.) Vuill. às formigas do gênero Acromyrmex (Hymenopetra: Formicidae). An. Soc. Entomol. Brasil 23:99-10

22. Von Arx, J.A. (1986). Tolypocladium, a Synomym of Beauveria. Mycotaxon 25:153-158 